\title{
Characterization of the annual regulation of reproductive and immune parameters on the testis of European sea bass
}

ARTICLE in CELL AND TISSUE RESEARCH · APRIL 2015

Impact Factor: 3.33 · DOI: 10.1007/s00441-015-2172-1 · Source: PubMed

DOWNLOADS

23
VIEWS

43

6 AUTHORS, INCLUDING:

Miriam Sánchez-Hernández

Instituto Español de Oceanografia

9 PUBLICATIONS 17 CITATIONS

SEE PROFILE

Alberto Cuesta

University of Murcia

97 PUBLICATIONS 2,036 CITATIONS

SEE PROFILE
Alfonsa García-Ayala

University of Murcia

86 PUBLICATIONS 1,213 CITATIONS

SEE PROFILE

Elena Chaves-Pozo

Instituto Español de Oceanografia

52 PUBLICATIONS 796 CITATIONS

SEE PROFILE 


\section{Characterization of the annual regulation of reproductive and immune parameters}

2 on the testis of European sea bass.

3 Short title: Reproductive cycle of one year old sea bass

4 Authors: Yulema Valero ${ }^{1}$, Miriam Sánchez-Hernández ${ }^{1}$, Alicia García-Alcázar ${ }^{1}$, $5 \quad$ Alfonsa García-Ayala ${ }^{2}$, Alberto Cuesta $^{2}$, Elena Chaves-Pozo ${ }^{1 *}$.

$6{ }^{1}$ Centro Oceanográfico de Murcia, Instituto Español de Oceanografía (IEO), Carretera 7 de la Azohía s/n. Puerto de Mazarrón, 30860 Murcia, Spain

$8 \quad{ }^{2}$ Department of Cell Biology and Histology, Faculty of Biology, Regional Campus of

9 International Excellence "Campus Mare Nostrum", University of Murcia, 30100

10 Murcia, Spain

11 Correspondence and reprint requests: *To whom correspondence should be

12 addressed to Centro Oceanográfico de Murcia, Instituto Español de Oceanografía,

13 Carretera de la Azohía s/n. Puerto de Mazarrón, 30860 Murcia, Spain.

14 elena.chaves@mu.ieo.es, fax: +34-968153934, tel: +34-968153339.

15 Keywords: European sea bass, cell renewal, testis, hormone levels, immune factors

17 Footnote ${ }^{1}$ : The genetic nomenclature used in this manuscript follow the guidelines of

18 Zebrafish Nomenclature Committee (ZNC) for fish genes and proteins and the HUGO

19 Gene Nomenclature committee for mammalian genes and proteins. 


\section{Abstract}

The European sea bass, Dicentrarchus labrax L., is a seasonal gonochoristic species, which males are generally mature during the second year of life. It has been demonstrated that cytokines and immune cells play a key role in the testicular development. This reproductive-immune interaction might be very important in the sea bass since several pathogens are able to colonize the gonad and persist in this tissue, altering further reproductive functions and spreading the disease. This study aims to investigate the reproductive cycle of one year European sea bass males by analyzing cell proliferation and apoptosis and expression profile of some reproductive and immune-related genes in the testis as well as the serum sex steroid levels. Our data demonstrate that in one year old European sea bass males, the testis undergoes the spermatogenesis process and that the reproductive and immune parameters analyzed varied during the reproductive cycle. In the testis, the highest proliferative rates were recorded at spermatogenesis stage, while the highest apoptotic rates were recorded at spawning stage. We have also analyzed, for the first time in European sea bass males, the serum levels of $17 \beta$-estradiol $\left(\mathrm{E}_{2}\right)$ and dihydrotestosterone and the gene expression profile of the enzymes implied in their production, determining that at least $\mathrm{E}_{2}$ might be involved in the regulation of the reproductive cycle. Some immune relevant genes, including cytokines, lymphocyte receptors, anti-viral and antibacterial molecules were detected in the testis of naïve European sea bass specimens and their expression profile was related with the stages of the reproductive cycle, suggesting an important role for the defence of the reproductive tissues. 


\section{Introduction}

Fish are the most diverse and numerous group of vertebrates. However, our knowledge on fish spermatogenesis is limited to a few species used in basic research and/or in aquaculture biotechnology. In the case of the European sea bass (Dicentrarchus labrax L.) most of the studies, as far as we are concern, dealing with gonad physiology are focussed on early hatch specimens until 300 days post-hatching (dph) or on mature specimens from two years old onwards. However, the events that occur in the gonad of one year old fish have been scarcely studied. Interestingly, data obtained in the gilthead seabream (Sparus aurata L.), a hermaphrodite species, points to the fact that captive specimens quickly differentiated the testicular area and produced spermatozoa even when the specimens are not spermiogenic active males (Chaves-Pozo et al., 2009).

The reproductive cycle of fish can be divided into four stages: spermatogenesis, spawning, post-spawning, and resting stages, according to the gonadosomatic index (GSI), the magnitude of some processes such as cell apoptosis and proliferation and the percentage of some cell types. In general, spermatogenesis stage is a complex developmental process, in which spermatogonia divide (renewal of spermatogonia stem cells and mitotic proliferation of spermatogonia), reduce their chromosome content by meiosis, and differentiate into spermatozoa. During post-spawning stage, an intensive remodelling of the testis occurs, while the enhancement of proliferation and the absence of apoptosis permit the repopulation of the testis by spermatogonia and Sertoli cells 66 during resting stage (Chaves-Pozo et al., 2005; Liarte et al., 2007). In teleost fish, 67 spermatogenesis is regulated by the interplay of systemic and intragonadal factors and the importance of each type of regulation vary depending on the developmental stage of the gonad (Schulz et al., 2010). Thus, the pituitary-derived gonadotropins, follicle- 
70 stimulating hormone (FSH) and luteinizing hormone ( $\mathrm{LH})$ regulate spermatogenesis by 71 acting directly on germ cells and indirectly by stimulating steroid hormone secretion 72 (Nagahama et al., 1994). In fact, plasma levels of sex steroids show important variations during the maturation of the male gonad. In fish, testosterone (T) and 11ketotestosterone $(11 \mathrm{KT})$ are generally considered the major and most potent circulating male androgens triggering spermatogenesis (Borg, 1994); however, recent data point to dihydrotestosterone (DHT) as another potent androgen, involved in regulating spermatogenesis in several fish species (Margiotta-Casaluci and Sumpter, 2011; Margiotta-Casaluci et al., 2013; Martyniuk et al., 2013). In the other hand, $17 \beta$-estradiol $\left(E_{2}\right)$ has been considered the main sex steroid of female fish, although some studies have suggested that estrogens are "essential" for normal male reproduction and might be involved in the recrudescence of the testis (Chaves-Pozo et al., 2007; Hess, 2003; Miura et al., 1999). Taken together, these data suggest that sex steroids have important and distinct roles in controlling fish spermatogenesis.

Recent studies have also demonstrated the importance of leukocytes and several immune factors in the regulation of the reproductive functions of the gonad. In fact, in teleosts, the presence of immune cells and the expression of several relevant immune genes in the gonad guarantees and modulate the reproductive functions (Chaves-Pozo et al., 2008; Chaves-Pozo et al., 2009; Chaves-Pozo et al., 2003) and also conditioned the immune response in the gonad allowing the persistence of several pathogens in those tissues (Chaves-Pozo et al., 2010a; Chaves-Pozo et al., 2010b). Although the immune

91 responses triggered in the European sea bass gonad has not been well documented, it is 92 true that sea bass is very susceptible to several pathogens able to colonize the gonad, persist on this tissue and be transmitted (Gómez-Casado et al., 2011; Sitja-Bobadilla and Álvarez-Pellitero, 1993). Moreover, some of those pathogens alter the efficiency of 
95 European sea bass reproduction and even block it (Sitja-Bobadilla and Álvarez-

96 Pellitero, 1993). Therefore, the characterization of the immune response, at both cellular

97 and molecular levels, in the sea bass gonad under naïve conditions is mandatory and necessary to understand how those pathogens interact or block it.

100 one year old European sea bass males, the testis morphology, the serum levels of some

101 sex steroid hormones and the expression profile of some reproductive genes. Moreover, we have analyzed the expression profile of some immune-relevant genes in the testis to demonstrate its presence and potential role in the defence of the reproductive tissues.

We also made an effort to correlate all these data in order to provide a wide overview of

105 the physiology of the testis in order to determine the more susceptible stages to 106 pathogens and to develop successful preventive treatments.

\section{Materials and Methods}

\subsection{Animals and experimental design}

Healthy European sea bass (Dicentrarchus labrax L., Actinopterygii,

111 Perciformes, Moronidae) specimens of one year old were bred and kept at the Centro

112 Oceanográfico de Murcia (IEO, Mazarrón, Murcia). The fish were kept in $12.5 \mathrm{~m}^{3}$

113 tanks with natural water temperature ranging from 14 to $26^{\circ} \mathrm{C}$, a flow-through circuit, a

114 suitable aeration and filtration system and a natural photoperiod. The specimens were

115 fed with a commercial dry pellet diet (Skretting) ad libitum. The environmental 116 parameters, mortality and food intake, were daily recorded.

117 The fish were sampled once a month ( $\mathrm{n}=8$ males/month) from September 2,010

118 (121 $\pm 42 \mathrm{~g}$ mean of body weight, bw) to May 2011 (222 $\pm 70 \mathrm{~g}$ mean of bw). The 
119 specimens were anesthetized with $40 \mu \mathrm{l} / 1$ of clove oil and blood was obtained from the 120 caudal peduncle and the serum samples, obtained by centrifugation $(10,000 \mathrm{~g}, 1 \mathrm{~min}, 4$

$12{ }^{\circ} \mathrm{C}$ ), were immediately frozen in liquid nitrogen and stored at $-80{ }^{\circ} \mathrm{C}$ until use for sex

122 steroid levels analysis. Then, specimens were weighed and decapitated, and the gonads

123 were removed, weighed and processed for light microscopy and gene expression

124 analysis as described below. Some specimens were intraperitoneally injected with 50

$125 \mathrm{mg} / \mathrm{kg}$ bw of 5-bromo-2'-deoxyuridine (BrdU, Sigma) $2 \mathrm{~h}$ before sampling. The

126 experiments described comply with the Guidelines of the European Union Council

127 (86/609/EU), the Bioethical Committee of the Instituto Español de Oceanografía

128 (Spain) and of the University of Murcia (Spain) for the use of laboratory animals.

\subsection{Light microscopy and immunocytochemical staining}

The gonads ( $\mathrm{n}=8 /$ month) were fixed in $4 \%$ paraformaldehyde solution, embedded in paraffin (Paraplast Plus; Sherwood Medical), and sectioned at $5 \mu \mathrm{m}$. Some sections were stained with hematoxylin-eosin to determine the sex and the reproductive stage of each fish. Other sections were used to determine cell proliferation being

134 subjected to an indirect immunocytochemical method using a monoclonal antibody anti-

135 BrdU (Becton Dickinson) at the optimal dilution of 1:100, that revealed the proliferative 136 cells which have incorporated the BrdU, previously injected, during their DNA 137 synthesis phase as described previously (Chaves-Pozo et al., 2005). Negative controls

138 have been done by omitting the first antiserum or by using tissue sections from fish that 139 had not been injected with BrdU. Other sections were subjected to in situ detection of 140 DNA fragmentation (TUNEL) assay to identify apoptotic cells (in situ cell death 141 detection kit; Roche) as described previously (Chaves-Pozo et al., 2007). Negative 142 controls were processed in an identical manner except that the TdT enzyme was 143 omitted. Positive controls were performed treating the sections with DNase I (3-3,000 
$144 \mathrm{U} / \mathrm{ml}$, Sigma) in $50 \mathrm{mM}$ Tris- $\mathrm{HCl} \mathrm{pH} 7.5,10 \mathrm{mM} \mathrm{MgCl}_{2}$, and $1 \mathrm{mg} / \mathrm{ml} \mathrm{BSA}$ for $10 \mathrm{~min}$

145 at room temperature to induce DNA strand breaks before labelling. All slides were 146 examined with a Nikon Eclipse E600 light microscope.

\section{2.3. Analytical techniques}

148 Serum ( $\mathrm{n}=4-6$ fish/reproductive stage) levels of T, $11 \mathrm{KT}$ and $\mathrm{E}_{2}$ were quantified 149 by ELISA following the method previously described (Rodríguez et al., 2000). Steroids

150 were extracted from $10 \mu \mathrm{l}$ of serum in $1.3 \mathrm{ml}$ of methanol (Panreac). Then, methanol was evaporated at $37^{\circ} \mathrm{C}$ and the steroids were resuspended in $400 \mu \mathrm{l}$ of reaction buffer [0,1 M phosphate buffer with 1mM EDTA (Sigma), $0.4 \mathrm{M} \mathrm{NaCl}$ (Sigma), $1.5 \mathrm{mM} \mathrm{NaN}_{3}$ (Sigma) and $0.1 \%$ albumin from bovine serum (Sigma)]. Samples of $50 \mu 1$ were

154 dispensed into wells of microtiter plates (MaxiSorp; Nunc) so that $1.25 \mu 1$ of serum were used in each well for all the assays. T, $11 \mathrm{KT}$ and $\mathrm{E}_{2}$ standards, mouse anti-rabbit

156 IgG monoclonal antibody $(\mathrm{mAb})$, and specific anti-steroid antibodies and enzymatic tracers (steroid acetylcholinesterase conjugates) were obtained from Cayman Chemical. A standard curve from $6.13 \times 10^{-4}$ to $5 \mathrm{ng} / \mathrm{ml}(0.03-250 \mathrm{pg} /$ well $)$, a blank and a nonspecific binding control (negative control) were established in all the assays. Standards

160 and extracted serum samples were run in duplicate and all the measures were corrected 161 with the blank and negative control. The lower limit of detection for all the assays was $24.4 \mathrm{pg} / \mathrm{ml}$. The intra-assay coefficients of variation (calculated from sample duplicates) were $4.06 \pm 1.02 \%$ for $\mathrm{T}, 6.00 \pm 1.53 \%$ for $11 \mathrm{KT}$ and $1.54 \pm 0.28 \%$ for $\mathrm{E}_{2}$ assays.

164 Details on cross-reactivity for specific antibodies were provided by the supplier ( $\mathrm{T}$ 165 cross-reacts $0.01 \%$ in the $11 \mathrm{KT}$ assay and $0.1 \%$ in the $\mathrm{E}_{2}$ assay; $11 \mathrm{KT}$ cross-reacts $2.2 \%$ 166 in the T assay). The serum ( $\mathrm{n}=4-6$ fish/reproductive stage) levels of dihydrotestosterone 167 (DHT) were quantified using the 5 $\alpha$-Dihydrotestosterone ELISA kit (DRG diagnostics) 
168 following the manufacturer's instructions. Details on cross-reactivity for specific

169 antibodies were provided by the supplier (T cross-reacts $8.7 \%$ in the DHT assay).

170

171

172

173

174

175

176

177

178

179

180

181

182

183

184

185

186

187

\subsection{Analysis of gene expression}

Total RNA was extracted from testis fragments ( $\mathrm{n}=7-12$ fish/reproductive stage) with TRIzol reagent (Invitrogen) following the manufacturer's instructions and treated with DNase I, amplification grade (1 unit/ $\mu$ g RNA, Invitrogen). SuperScript III RNase $\mathrm{H}^{-}$Reverse Transcriptase (Invitrogen) was used to synthesize first strand cDNA with oligo-dT18 primer from $1 \mu \mathrm{g}$ of total RNA, at $50{ }^{\circ} \mathrm{C}$ for $60 \mathrm{~min}$.

The expression of some genes was analyzed by real-time PCR performed with an ABI PRISM 7500 instrument (Applied Biosystems) using SYBR Green PCR Core Reagents (Applied Biosystems) as previously described (Chaves-Pozo et al., 2008). These genes code for (i) steroidogenic enzymes such as steroid 11- $\beta$-hydroxylase (cyp11b1), 3ß-hydroxysteroid dehydrogenase (dhs3b), and aromatase (cyp19a1a); (ii) the anti-Mullerian hormone (amh); (iii) hormone receptors such as follicle stimulating hormone receptor ( $f$ shr), and estrogen receptor $\beta 1$ (erb1), and erb2; (iv) cytokines such as interleukin $1 \beta(\mathrm{il1b})$, il6, and tumour necrosis factor $\alpha$ (tnfa); (v) lymphocyte receptors such as the heavy chain of immunoglobulin $\mathrm{M}$ (ighm) and the $\beta$ subunit of Tcell receptor (tcrb); (vi) viral recognition molecules such as melanoma differentiationassociated 5 protein $(m d a 5)$ and laboratory of genetics and physiology 2 protein $(\operatorname{lgp} 2)$, anti-viral signalling pathway molecules such as TANK-binding kinase 1 (tbk1) and interferon regulatory factor 3 (irf3) and anti-viral response molecules such as interferon (ifn), anti-viral protein kinase $(p k r)$ and myxovirus (influenza) resistance proteins $(m x)$; and (v) anti-bacterial molecules such as lysozyme (lyz), complement component 3 (c3), dicentracin (dic), hepcidin (hamp), and the histones H1 (h1) and H2B (h2b). For each mRNA, gene expression was corrected by the elongation factor 1 alpha gene (ef1a) 
193 content in each sample. The European sea bass specific primers used are shown in Table

194 1. Some genes were identified in the expressed sequence tags (ESTs) databases and

195 Table 2 shows their relation with the zebrafish orthologs. Before the experiments, the

196 specificity of each primer pair was studied using positive and negative samples.

197 Amplified products from positive samples were purified and sequenced. In all cases,

198 each PCR was performed in triplicate wells. The ef1a gene expression showed $2 \%$ of

199 variability across stages.

\subsection{Calculation and statistics}

The gonadosomatic index (GSI) was calculated as an index of the reproductive stage $[100 *(\mathrm{MG} / \mathrm{MB})(\%)]$, where $\mathrm{MG}$ is gonad mass (in grams) and $\mathrm{MB}$ is body mass 203 (in grams).

The quantification of proliferative $\left(\mathrm{BrdU}^{+}\right)$and apoptotic cell areas was calculated as the mean value \pm SEM of the stained area/total area of 50 randomly distributed optical areas at $200 \times$ magnifications. The stained areas were measured by image analysis using a Nikon Eclipse E600 light microscope, an Olympus SC30 digital camera (Olympus soft imaging solutions GMBH), and Leica Qwin software (Leica microsystems).

All data were analyzed by one-way ANOVA and a Duncan post hoc test to

211 determine differences between groups $(\mathrm{P} \leq 0.05)$. Normality of the data was previously assessed using a Shapiro-Wilk test and homogeneity of variance was also verified using

213 the Levene test. A non-parametric Kruskal-Wallis test was used when data did not meet

214 parametric assumptions. In addition, non-parametric Pearson correlation tests were 215 applied to test correlations among hormonal levels and gene expression levels. 216 Statistical analyses were conducted using SPPS 15.0 software (SPSS). 


\section{3. Results}

3.1. The reproductive cycle is completed in one year old European sea bass specimens.

We observed that the reproductive cycle of one year old European sea bass

222 males is divided in four stages according to the GSI (Fig. 1a) and the testicular 223 morphology (Fig. 1b-j). Thus, at resting stage, the GSI was low and the testis was

224 formed by tubules without lumen or with a very small lumen and mainly formed by cysts of spermatogonia (Fig. 1b,c). At spermatogenesis stage, the spermatogonia start to progress through the spermatogenetic process and cysts of more developed germ cells appeared (Fig. 1d-f). As spermatogenesis progresses, the GSI progressively increased (Fig. 1a) and the amount of cysts of spermatocytes, spermatids and spermatozoa and the amount of free spermatozoa in the lumen of the tubules were more visible, while the amount of cysts of spermatogonia were proportionally less visible (Fig. 1d-f). At spawning stage, the GSI reached its maximum and sharply decreased when the spermatozoa and the seminal fluid is released (Fig. 1a) and the tubules contained some cysts of spermatocytes, spermatids and a few cysts of spermatogonia which delimited a

234 large lumen full of free spermatozoa (Fig. 1g) and the deferent duct is full of free 235 spermatozoa (Fig. 1h). At post-spawning stage, the GSI showed a great variability and non-statistically significant difference respect the previous month was observed (Fig. 1a). At this stage, the tubules were formed by cysts of spermatogonia and single Sertoli 238 cells that limited the lumen of the tubules which appeared empty and reduced in size 239 (Fig. 1i,j). 

spawning.

The proliferative (Fig. 2) and apoptotic (Fig. 3) rates were related with the observed changes in the GSI and the testicular morphology (Fig. 1). At resting stage, the

244 proliferative rate was low as only some spermatogonia were immunostained (Fig. 2a,b).

245 However, at spermatogenesis stage, the proliferative rate reached its maximum value 246 due to the proliferation of spermatogonia and Sertoli cells (Fig. 2a,c). Later on, the 247 proliferative rates decreased to minimum levels that kept steady during spawning and post-spawning stages (Fig. 2a). In these stages only spermatogonia proliferated (Fig. $2 \mathrm{~d}, \mathrm{e})$. Regarding the apoptosis rate, the maximum value was recorded at spawning stage and there were no differences on the apoptotic rates at resting, spermatogenesis or postspawning stages (Fig. 3a). The TUNEL positive cells were some spermatogonia and Sertoli cells at resting stage (Fig. 3b), some Sertoli cells or interstitial cells at spermatogenesis stage (Fig. 3c) and the Sertoli cells that limited the lumen of the tubules at spawning (Fig. 3d) and post-spawning (Fig. 3g) stages. In addition, numerous remaining spermatozoa present on the lumen of the tubules were TUNEL positive cells at spawning stage (Fig. 3d,e). Interestingly, some TUNEL positive spermatozoa were located in the cytoplasm of the cells that limited the efferent ducts (Fig. 3f).

\section{3. $T, 11 \mathrm{KT}$ and $E_{2}$ serum levels varied through the reproductive cycle.}

In one year old European sea bass the serum levels of $\mathrm{T}$ were increased at spermatogenesis stage, kept high during spawning stage and decreased at post-spawning

261 stage reaching levels similar to those observed at resting stage (Fig. 4a). However, the

$26211 \mathrm{KT}$ serum levels showed the greatest variation reaching its maximum level at spermatogenesis stage and progressively decreasing until its minimum level at postspawning stage, which is lower than the level recorded during resting stage (Fig. 4b). 
265 However, the serum levels of DHT did not show any modification during the 266 reproductive cycle analyzed (Fig. 4c). Interestingly, the levels of $\mathrm{T}$ were positively 267 correlated with the levels of $11 \mathrm{KT}$ and DHT, although $11 \mathrm{KT}$ and DHT serum levels did 268 not correlated (Table 3). Regarding estrogens, the serum levels of $E_{2}$ increased after 269 resting and kept steady onwards (Fig. 4d). The serum levels of $\mathrm{E}_{2}$ did not correlated 270 with the levels of any androgen studied (Table 3).

3.4. Most of the steroidogenetic, hormones and hormones receptor gene expressions were undetected at spawning stage.

The cyp11b1 gene, codifies an enzyme (11ß-hydroxylase) shared by the glucocorticoid (mainly produced in the interrenal tissue) and androgen (mainly produced in the gonad) pathway. This enzyme converts 11-deoxycortisol to cortisol and also participates in the final steps of the synthesis of the 11-oxigenated androgens being involved in the transformation of $\mathrm{T}$ to DHT than later on is transformed to $11 \mathrm{KT}$. The expression levels of cyp $11 \mathrm{~b} 1$ in the gonad, the main synthesis site of androgens, were high at spermatogenesis and post-spawning stages and very low during spawning stage (Fig. 5a). However, the expression levels of dhs3b (Fig. 5b) and cyp19a1a (Fig. 5c) were similar during resting, spermatogenesis and post-spawning stages, but not detected at spawning stage. The expression pattern levels of amh gene were low during resting and spermatogenesis stages and not detectable at spawning stage; however, increased during post-spawning stage (Fig. 5d). Regarding the expression of the genes that code 285 for hormone receptors, the $f$ shr gene expression was low during resting and 286 spermatogenesis stages, not detectable at spawning stage and increased at post287 spawning stage (Fig. 5e). The expression levels of erb1 were low during resting, spermatogenesis and spawning stages and increased at post-spawning stage (Fig. $5 f$ ). However, the mRNA levels of erb2 were similar during resting, spermatogenesis and 
post-spawning stages and not detectable at spawning stage (Fig. 5g). The levels of expression of $d h s 3 b$ were positively correlated with $\mathrm{T}$ and negative correlated with $f s h r$ gene expression (Table 3). As expected, the transcript levels of cyp19a1a showed a negative correlation with $\mathrm{T}$ serum levels (Table 3), although this gene expression

294 showed a positive correlation with the expression of cyp11b1 gene (Table 3). Moreover,

295 the expression level of cyp11b1 gene was positively correlated with the serum levels of

$296 \mathrm{E}_{2}$ and with the transcription levels of amh, erb1 and fshr genes (Table 3). Additionally

297 the expression of erb2 gene showed a positive correlation with the expression of amh and erb1 genes, while the transcript levels of fshr gene correlated with transcript levels of amh, erb1 and erb2 genes (Table 3).

3.5. Immune-related genes are expressed in the testis and changed with the reproductive cycle.

We next determined the presence and status of the immune response in the gonad. For then, we analyzed the expression of several immune-relevant molecules such as: cytokines (il1b, il6 and tnfa), immune receptors (ighm and tcrb) (Fig. 6), viral recognition molecules ( $m d a$ and lgp2), anti-viral signalling pathway molecules (tbk1 and irf3), anti-viral response molecules (ifn, pkr and $m x$ ) (Fig. 7) and antimicrobial peptides (lyz, c3, dic, hamp, h1 and h2b) (Fig. 8). Thus, the il1b expression (Fig. 6a) decreased during spermatogenesis and spawning stages and showed the same levels of expression during resting and post-spawning stages. The il6 expression (Fig. 6b) also

311 showed similar levels at resting, spawning and post-spawning stages and slightly 312 decreased during spermatogenesis stage. The expression of tnfa (Fig. 6c), however, did 313 not show any statistically significant change during the reproductive cycle. Regarding 314 the immune receptors (Fig. 6d,e), the expression of both, ighm and tcrb, genes increased 
315 at spermatogenesis stage, however, while the expression of ighm decreased later on

316 showing similar levels of expression during resting, spawning and post-spawning stages

317 (Fig. 6d), the expression of tcrb was kept steady from spermatogenesis stage onwards

318 (Fig. 6e). Most of the anti-viral molecules analyzed (Fig. 7) showed a basal expression

319 that did not change throughout the reproductive cycle, with the exception of the single

320 stranded RNA receptor coding gene, the lgp2 (Fig. 7b), a interferon response factor

321 coding gene, the irf3 (Fig. 7d), and a interferon response molecule coding gene, the pkr

322 (Fig. 7f), which expression increased at spawning stage. Regarding the antimicrobial

323 peptides analyzed, hepcidin dicentracin, lysozyme and complement factor 3 are well

324 characterized in terms of molecular sequences and gene expression profiles that related

325 those proteins to innate immune responses (Rodríguez et al., 2006; Salerno et al., 2007;

326 Buonocore et al., 2014). In the case of histones, fish proteins highly homologous to or

327 identical to core nuclear histones have been identified and linked to innate defence

328 (Noga et al., 2011; Valero et al., 2013) but further characterization is still needed at

329 molecular and functional levels. Our data revealed different patterns of expression of

330 these genes (Fig. 8). Thus, the expression of lyz (Fig. 8a) and c3 (Fig. 8b) increased at

331 spermatogenesis stage, remaining high during the rest of the reproductive cycle in the

332 case of lyz or decreased at spawning stage in the case of $c 3$. The dic gene expression

333 (Fig. 8c) progressively increased from spermatogenesis stage to spawning stage when it

334 reached its maximum levels decreasing later on at post-spawning stage to the levels

335 observed at resting stage. The $h 1$ gene expression (Fig. 8e) decreased at

336 spermatogenesis stage, was not detectable at spawning stage and increased at post-

337 spawning stage, while the expression of hamp (Fig. 8d) and $h 2 b$ (Fig. 8f) genes was

338 kept unchanged throughout the reproductive cycle. 


\section{Discussion}

In teleost fish, spermatogenesis is regulated by the interplay of systemic and intragonadal factors and the importance of each type of regulation vary depending on the developmental stage of the gonad (Schulz et al., 2010). Our data demonstrate that in

344 one year old fish, the testis undergo the complete spermatogenesis process although it 345 was previously described that European sea bass males mature after two years of age

346 (Carrillo et al., 1995). Interestingly, the proliferative rates of germ cells on the testis of 347 teleosts are known to be regulated by endocrine and paracrine factors. Thus, in several 348 fish species, FSH, androgens and estrogens have been reported to trigger germ or Sertoli 349 cell proliferation, while other factors like AMH prevents this proliferation (Mazon et al., 350 2014; Miura et al., 2002; Miura et al., 1999; Miura et al., 1991; Skaar et al., 2011). In 351 the sea bass, FSH regulates Sertoli cell proliferation (Mazon et al., 2014) and the expression of fshr gene has also been related with early stages of the gonad development and with Sertoli cell proliferation (Rocha et al., 2009). However, in one year old European sea bass, the fshr gene expression is higher at post-spawning as also occurs with other reproductive genes analyzed as cyp11b1, erb1, erb2 and amh. Interestingly, most of the reproductive genes analyzed showed non detectable levels of transcription at spawning that could be explained due to the dilution of somatic cells with respect to the high amount of spermatozoa together with a lower transcription level of those genes. In fact, in two year old sea bass, a decrease in the expression levels of

360 some reproductive genes such as fshr and cyp11b1 at the final stages of spermatogenesis

361 was observed (Rocha et al., 2009). Thus, the fshr and cyp11b1 gene expressions showed

362 similar patterns in these two populations of fish (Rocha et al., 2009). It is worthy to note that even when the levels of expression of these genes is very low and not detected in our real time PCR assay, these levels could be enough to maintain serum hormone 
365 levels. Moreover, the precise relation among the mRNA transcripts, enzyme activity and

366 hormone levels is unknown, an aspect that might be worthy to asses in a future.

Our data demonstrate that European sea bass apoptosis is involved in the depletion of the remaining spermatozoa after spawning as determined by the massive spermatozoa stained by TUNEL, an issue that do not occurs in all fish species.

370 Interestingly, the elimination of remained spermatozoa is a variable process in different species of vertebrates independently of their taxonomical association. Thus, in a seasonal breeder mammal, the Iberian mole (Talpa occidentalis) (Dadhich et al., 2010), and in a teleostean fish, the gilthead seabream (Chaves-Pozo et al., 2005), apoptosis is not involved in the depletion of spermatozoa after spawning, while in other mammalian species as the mink (Mustela vison) (Blottner et al., 1999) and in the teleostean European sea bass (as our data demonstrate) apoptosis has a prominent role. Moreover, as European sea bass spermatozoa underwent apoptosis, the apoptotic spermatozoa are in turn phagocytosed by the Sertoli cells that limited the lumen of the tubules, as the presence of this apopototic cells, determined by the TUNEL staining, in the cytoplasm of the Sertoli cells that limited the efferent ducts suggests, as also occurred in other vertebrates (Carr et al., 1968; Shiratsuchi et al., 1997). increased at spermatogenesis stage and decreased during spawning and post-spawning stages. This pattern of $11 \mathrm{KT}$ production has also been described in two years old sea bass males (Rocha et al., 2009). DHT has been considered to be a major androgen in many male vertebrates (Borg, 1994) and physiologically important in some fish species

387 (Margiotta-Casaluci and Sumpter, 2011, Margiotta-Casaluci et al., 2013) but not in others (Cavaco et al., 1998). Although the function of DHT in teleosts is not clear yet, there are growing lines of evidence that teleost fish are capable of synthesizing DHT 
390 (Martyniuk et al., 2013; Sánchez-Hernández et al., 2013). Interestingly, we have

391 detected low levels of DHT in one year old European sea bass serum, which were kept 392 steady throughout the reproductive cycle. Moreover, our data showed that DHT serum

393 levels positively correlated with $\mathrm{T}$ serum levels, suggesting that the variation of $\mathrm{T}$ is 394 important for the maintenance of DHT levels. In addition, the mean T/DHT ratio was 395 calculated and resulted of 12 in fathead minnow males and of 20 in females (Margiotta396 Casaluci et al., 2013) in a similar way to the one year sea bass males which showed a 397 mean ratio of 13.22 (ranging from 4.5 to 20.3). DHT levels might be kept steady thanks 398 to its transformation into $\beta$-diol as suggested by the regulation of $d h s 3 b$ transcription 399 levels. As occurs with DHT, the serum levels of $E_{2}$ were also very low in European sea 400 bass males although they increased slightly from spermatogenesis onwards. $E_{2}$ has been 401 related in several teleost fish species with the final events of spermatogenesis stage and 402 the regulation of germ and Sertoli cells proliferation and apoptosis (Chaves-Pozo et al., 403 2007; Miura et al., 1999). However, high levels of $E_{2}$ triggered spermatogenesis 404 disruption and sex change in vertebrates including fish species (Chaves-Pozo et al., 405 2007; Condeca and Canario, 1999; O'Donnell et al., 2001). Our data showed a negative 406 correlation between cyp19a1a gene expression and T serum levels, suggesting that the 407 regulation of cyp19a1a gene expression is an important point of regulation to allow the 408 maintenance of male physiology and explaining the effectiveness of estrogenic disruptor 409 pollutants to affect male physiology (Martinovic et al., 2007). Interestingly, $\mathrm{E}_{2}$ has also been related to the recruitment of leukocytes and the 411 regulation of the cytokine network of the immune response in the gonad (Cabas et al., 412 2011; Seemann et al., 2013). The regulation of the immune response in the gonad of 413 teleost fish to avoid germ cell damage allows the persistence of several pathogens in 414 those tissues (Chaves-Pozo et al., 2010a; Chaves-Pozo et al., 2010b). The European sea 
415 bass is very susceptible to several pathogens able to colonize the gonad, persist on this

416 tissue and be transmitted (Gómez-Casado et al., 2011; Sitja-Bobadilla and Álvarez-

417 Pellitero, 1993). In this framework, we have analyzed the gene expression pattern of

418 several pro-inflammatory cytokines, lymphocyte receptors and anti-viral and anti-

419 bacterial molecules in one year old European sea bass testis. In general, we observed

420 that the expression levels of the pro-inflammatory cytokines are low at spermatogenesis

421 and spawning stages while the gene expression of ighm and tcrb genes, together with 422 several anti-viral molecules (lgp2, tbk1 and $p k r)$ and antimicrobial peptides (lyz, dic, c3)

423 increased at spermatogenesis and/or spawning stages. These increments could be 424 explained due to protective reasons to infection during the sperm storage in the efferent 425 ducts until the release of spermatozoa.

Histones package DNA in all eukaryotes and play key roles in regulating gene expression. Interestingly, in mammals and birds, the linker histone H1 display tissue specificity and encompass a variety of important biological processes, including cellular proliferation and apoptosis. Moreover, it has been recently described their functions as antimicrobial peptides (AMPs) in vertebrates linking them to the immunity. In fish, proteins highly homologous to or identical to core nuclear histones have been identified and linked to innate defence, and more concretely to the antimicrobial response (Noga et al., 2011; Valero et al., 2013). In this framework, our data show that the $h 1$ transcription profiles suggest that the European sea bass substitute the H1 histone of 435 germ cells with protamines or other sperm-specific histones, as spermatogenesis 436 proceeds, as occur in mammals and in contrast to what happens in other fish species 437 when histones are not fully or partially replaced (Saperas et al., 1994; Yan et al., 2003). 438 Moreover, $h 2 b$ expression was kept steady through the reproductive cycle instead of 439 being decreased, as expected in the case that this fish species replace the core histones, 
440 or increased, as expected in the case that this fish species did not replace the core 441 histones. Taken all this data together, we can suggest that $\mathrm{H} 2 \mathrm{~b}$ has a role other than 442 DNA packaging.

443 Our data demonstrate that in one year old European sea bass males, the testis 444 undergoes the complete spermatogenesis process, although these specimens are not 445 considered fully mature. Moreover, serum levels of $11 \mathrm{KT}$ and $\mathrm{T}$ and the gene 446 expression profile of the steroidogenic enzymes involved in their synthesis varied 447 during the reproductive cycle. We have described for the first time in European sea bass 448 males, the serum levels of $\mathrm{E}_{2}$ and DHT, determining that at least $\mathrm{E}_{2}$ might be involved 449 in the regulation of the reproductive cycle of European sea bass males as also occurs in 450 other species of teleosts. Regarding the status of the immune response on the gonad, our 451 data showed high levels of expression of several AMPs such as lysozyme, C3 or 452 dicentracin during spermatogenesis and spawning and lower levels of pro-inflammatory 453 cytokines at the same stages, suggesting an important role for AMPs in the defence of 454 the reproductive tissues.

455 5. Conflict of interest: The authors declare that they have no conflict of interest.

456 6. Funding: This work was supported by grants of the Ministerio de Economía $y$ 457 Competitividad and FEDER (AGL2010-20801-C02-01, AGL2010-20801-C02-02 and 458 AGL2011-30264-C02-01) and Fundación Séneca (Grupo de Excelencia de la Región 459 de Murcia 04538/GERM/06).

460 7. Acknowledgement

461 Elena Chaves-Pozo thanks the Ministerio de Economía y Competitividad for her Ramón 462 y Cajal's research contract and Yulema Valero and Miriam Sánchez-Hernandez thanks 463 the Instituto Español de Ocenaografía for their PhD grants. 
465

466

467

468

469

470

471

472

473

474

475

476

477

478

479

480

481

482

483

484

485

486

487

488

489

490

491

492

493

494

495

496

497

498

499

500

501

502

503

504

505

506

507

508

509

510

511

512

Blázquez M., González A., Papadaki M., Mylonas C. and Piferrer F. (2008) Sex-related changes in estrogen receptors and aromatase gene expression and enzymatic activity during early development and sex differentiation in the European sea bass (Dicentrarchus labrax). Gen Comp Endocrinol 158, 95-101.

Blottner S., Roelants H., Wagener A. and Wenzel U. D. (1999) Testicular mitosis, meiosis and apoptosis in mink (Mustela vison) during breeding and nonbreeding seasons. Anim Reprod Sci 57, 237-49.

Borg B. (1994) Androgens in teleost fishes. Comp. Biochem. Physiol. 109 C, 219-245.

Buonocore F., Randelli E., Trisolino P., Facchiano A., de Pascale D. and Scapigliati G. (2014) Molecular characterization, gene structure and antibacterial activity of a g-type lysozyme from the European sea bass (Dicentrarchus labrax L.). Mol Immunol 62, 10-8.

Buonocore F., Castro R., Randelli E., Lefranc M. P., Six A., Kuhl H., Reinhardt R., Facchiano A., Boudinot P. and Scapigliati G. (2012) Diversity, molecular characterization and expression of $\mathrm{T}$ cell receptor gamma in a teleost fish, the sea bass (Dicentrarchus labrax, L). PLoS One 7, e47957.

Cabas I., Chaves-Pozo E., García-Alcázar A., Meseguer J., Mulero V. and García-Ayala A. (2011) Dietary intake of 17alpha-ethinylestradiol promotes leukocytes infiltration in the gonad of the hermaphrodite gilthead seabream. Mol Immunol 48, 2079-2086.

Carr I., Clegg E. J. and Meek G. A. (1968) Sertoli cells as phagocytes: an electron microscopic study. J Anat 102, 501-509.

Carrillo M., Zanuy S., Prat F., Cerda J., Ramos J., Mananos E. and Bromage N. (1995) Sea Bass (Dicentrarchus labrax). In Broodstock management and egg and larval quality (Edited by Bromage N. R. and Roberts R. J.), p. 138-168. Blackwell Science Ltd, Oxford.

Casani D., Randelli E., Costantini S., Facchiano A. M., Zou J., Martin S., Secombes C. J., Scapigliati G. and Buonocore F. (2009) Molecular characterisation and structural analysis of an interferon homologue in sea bass (Dicentrarchus labrax L.). Mol Immunol 46, 943-952.

Cavaco J. E., Vilrokx C., Trudeau V. L., Schulz R. W. and Goos H. J. (1998) Sex steroids and the initiation of puberty in male African catfish (Clarias gariepinus). Am J Physiol 275, R1793-1802.

Chaves-Pozo E., Liarte S., Fernández-Alacid L., Abellán E., Meseguer J., Mulero V. and García-Ayala A. (2008) Pattern of expression of immune-relevant genes in the gonad of a teleost, the gilthead seabream (Sparus aurata L.). Mol Immunol 45, 2998-3011.

Chaves-Pozo E., Liarte S., Mulero I., Abellán E., Meseguer J. and García-Ayala A. (2009) Early presence of immune cells in the developing gonad of the gilthead seabream (Sparus aurata Linnaeus, 1758). J Reprod Dev 55, 440-445.

Chaves-Pozo E., Liarte S., Vargas-Chacoff L., García-López A., Mulero V., Meseguer J., Mancera J. M. and García-Ayala A. (2007) 17Beta-estradiol triggers postspawning in spermatogenically active gilthead seabream (Sparus aurata L.) males. Biol Reprod 76, 142-148.

Chaves-Pozo E., Montero J., Cuesta A. and Tafalla C. (2010a) Viral hemorrhagic septicemia and infectious pancreatic necrosis viruses replicate differently in rainbow trout gonad and induce different chemokine transcription profiles. Dev Comp Immunol 34, 648-658. 
Chaves-Pozo E., Mulero V., Meseguer J. and García-Ayala A. (2005) An overview of cell renewal in the testis throughout the reproductive cycle of a seasonal breeding teleost, the gilthead seabream (Sparus aurata L). Biol Reprod 72, 593601.

Chaves-Pozo E., Pelegrín P., Mulero V., Meseguer J. and García-Ayala A. (2003) A role for acidophilic granulocytes in the testis of the gilthead seabream (Sparus aurata L., Teleostei). J Endocrinol 179, 165-174.

Chaves-Pozo E., Zou J., Secombes C. J., Cuesta A. and Tafalla C. (2010b) The rainbow trout (Oncorhynchus mykiss) interferon response in the ovary. Mol Immunol 47, 1757-1764.

Condeca J. B. and Canario A. V. (1999) The effect of estrogen on the gonads and on in vitro conversion of androstenedione to testosterone, 11-ketotestosterone, and estradiol-17beta in Sparus aurata (Teleostei, Sparidae). Gen Comp Endocrinol 116, 59-72.

Dadhich R. K., Real F. M., Zurita F., Barrionuevo F. J., Burgos M. and Jiménez R. (2010) Role of apoptosis and cell proliferation in the testicular dynamics of seasonal breeding mammals: a study in the Iberian mole, Talpa occidentalis. Biol Reprod 83, 83-91.

Gómez-Casado E., Estepa A. and Coll J. M. (2011) A comparative review on Europeanfarmed finfish RNA viruses and their vaccines. Vaccine 29, 2657-71.

Halm S., Rocha A., Miura T., Prat F. and Zanuy S. (2007) Anti-Mullerian hormone $(\mathrm{AMH} / \mathrm{AMH})$ in the European sea bass: its gene structure, regulatory elements, and the expression of alternatively-spliced isoforms. Gene 388, 148-58.

Halm S., Martinez-Rodriguez G., Rodriguez L., Prat F., Mylonas C. C., Carrillo M. and Zanuy S. (2004) Cloning, characterisation, and expression of three oestrogen receptors (ERalpha, ERbeta1 and ERbeta2) in the European sea bass, Dicentrarchus labrax. Mol Cell Endocrinol 223, 63-75.

Hess R. A. (2003) Estrogen in the adult male reproductive tract: a review. Reprod Biol Endocrinol 1, 1-52.

Liarte S., Chaves-Pozo E., García-Alcázar A., Mulero V., Meseguer J. and GarcíaAyala A. (2007) Testicular involution prior to sex change in gilthead seabream is characterized by a decrease in DMRT1 gene expression and by massive leukocyte infiltration. Reprod Biol Endocrinol 5, 20-35.

Margiotta-Casaluci L. and Sumpter J. P. (2011) 5alpha-Dihydrotestosterone is a potent androgen in the fathead minnow (Pimephales promelas). Gen Comp Endocrinol 171, 309-318.

Margiotta-Casaluci L, Courant F, Antignac JP, Le Bizec B, Sumpter JP. Identification and quantification of $5 \alpha$-dihydrotestosterone in the teleost fathead minnow (Pimephales promelas) by gas chromatography-tandem mass spectrometry. Gen Comp Endocrinol. 2013 Sep 15;191:202-209. doi: 10.1016/j.ygcen.2013.06.017.

Martinovic D., Hogarth W. T., Jones R. E. and Sorensen P. W. (2007) Environmental estrogens suppress hormones, behavior, and reproductive fitness in male fathead minnows. Environ Toxicol Chem 26, 271-8.

Martyniuk C. J., Bissegger S. and Langlois V. S. (2013) Current perspectives on the androgen 5 alpha-dihydrotestosterone (DHT) and 5 alpha-reductases in teleost fishes and amphibians. Gen Comp Endocrinol 194, 264-74.

Mauri I., Roher N., MacKenzie S., Romero A., Manchado M., Balasch J. C., Béjar J., Álvarez M. C. and Tort L. (2011) Molecular cloning and characterization of European sea bass (Dicentrarchus labrax) and Gilthead seabream (Sparus aurata) complement component C3. Fish Shellfish Immunol 30, 1310-1322. 
Mazón M. J., Gómez A., Yilmaz O., Carrillo M. and Zanuy S. (2014) Administration of follicle-stimulating hormone in vivo triggers testicular recrudescence of juvenile European sea bass (Dicentrarchus labrax). Biol Reprod 90, 1-10.

Miura T., Miura C., Konda Y. and Yamauchi K. (2002) Spermatogenesis-preventing substance in Japanese eel. Development 129, 2689-97.

Miura T., Miura C., Ohta T., Nader M. R., Todo T. and Yamauchi K. (1999) Estradiol17 beta stimulates the renewal of spermatogonial stem cells in males. Biochem Biophys Res Commun 264, 230-4.

Miura T., Yamauchi K., Takahashi H. and Nagahama Y. (1991) Hormonal induction of all stages of spermatogenesis in vitro in the male Japanese eel (Anguilla japonica). Proc Natl Acad Sci U S A 88, 5774-8.

Nagahama Y., Miura T. and Kobayashi T. (1994) The onset of spermatogenesis in fish. Ciba Found Symp 182, 255-270.

Nascimento D. S., Pereira P. J., Reis M. I., do Vale A., Zou J., Silva M. T., Secombes C. J. and dos Santos N. M. (2007) Molecular cloning and expression analysis of sea bass (Dicentrarchus labrax L.) tumor necrosis factor-alpha (TNF-alpha). Fish Shellfish Immunol 23, 701-710.

Noga E. J., Ullal A. J., Corrales J. and Fernandes J. M. (2011) Application of antimicrobial polypeptide host defenses to aquaculture: Exploitation of downregulation and upregulation responses. Comp Biochem Physiol Part D Genomics Proteomics 6, 44-54.

O'Donnell L., Robertson K. M., Jones M. E. and Simpson E. R. (2001) Estrogen and spermatogenesis. Endocr Rev 22, 289-318.

Rocha A., Zanuy S., Carrillo M. and Gómez A. (2009) Seasonal changes in gonadal expression of gonadotropin receptors, steroidogenic acute regulatory protein and steroidogenic enzymes in the European sea bass. Gen Comp Endocrinol 162, 265-75.

Rocha A., Gómez A., Zanuy S., Cerda-Reverter J. M. and Carrillo M. (2007) Molecular characterization of two sea bass gonadotropin receptors: cDNA cloning, expression analysis, and functional activity. Mol Cell Endocrinol 272, 63-76.

Rodríguez L., Begtashi I., Zanuy S. and Carrillo M. (2000) Development and validation of an enzyme inmunoassay for testosterone: effects of photoperiod on plasma testosterone levels and gonadal development in male sea bass (Dicentrarchus labrax, L.) at puberty. Fish Physiol. Biochem. 23, 141-150.

Rodrigues P. N., Vazquez-Dorado S., Neves J. V. and Wilson J. M. (2006) Dual function of fish hepcidin: response to experimental iron overload and bacterial infection in sea bass (Dicentrarchus labrax). Dev Comp Immunol 30, 11561167.

Salerno G., Parrinello N., Roch P. and Cammarata M. (2007) cDNA sequence and tissue expression of an antimicrobial peptide, dicentracin; a new component of the moronecidin family isolated from head kidney leukocytes of sea bass, Dicentrarchus labrax. Comp Biochem Physiol B Biochem Mol Biol 146, 521529.

Sánchez-Hernández M., Chaves-Pozo E., Cabas I., Mulero V., García-Ayala A. and García-Alcázar A. (2013) Testosterone implants modify the steroid hormone balance and the gonadal physiology of gilthead seabream (Sparus aurata L.) males. J Steroid Biochem Mol Biol 138C, 183-194.

Saperas N., Ausio J., Lloris D. and Chiva M. (1994) On the evolution of protamines in bony fish: alternatives to the "retroviral horizontal transmission" hypothesis. $J$ Mol Evol 39, 282-295. 
Scapigliati G., Buonocore F., Randelli E., Casani D., Meloni S., Zarletti G., Tiberi M., Pietretti D., Boschi I., Manchado M., Martin-Antonio B., Jimenez-Cantizano R., Bovo G., Borghesan F., Lorenzen N., Einer-Jensen K., Adams S., Thompson K., Alonso C., Bejar J., Cano I., Borrego J. J. and Alvarez M. C. (2010) Cellular and molecular immune responses of the sea bass (Dicentrarchus labrax) experimentally infected with betanodavirus. Fish Shellfish Immunol 28, 303311.

Scapigliati G., Buonocore F., Bird S., Zou J., Pelegrin P., Falasca C., Prugnoli D. and Secombes C. J. (2001) Phylogeny of cytokines: molecular cloning and expression analysis of sea bass Dicentrarchus labrax interleukin-1beta. Fish Shellfish Immunol 11, 711-726.

Schulz R. W., de Franca L. R., Lareyre J. J., Le Gac F., Chiarini-García H., Nobrega R. H. and Miura T. (2010) Spermatogenesis in fish. Gen Comp Endocrinol 165, 390-411.

Seemann F., Knigge T., Rocher B., Minier C. and Monsinjon T. (2013) 17 betaEstradiol induces changes in cytokine levels in head kidney and blood of juvenile sea bass (Dicentrarchus labrax, L., 1758). Mar Environ Res 87-88, 4451.

Sepulcre M. P., Sarropoulou E., Kotoulas G., Meseguer J. and Mulero V. (2007) Vibrio anguillarum evades the immune response of the bony fish sea bass (Dicentrarchus labrax L.) through the inhibition of leukocyte respiratory burst and down-regulation of apoptotic caspases. Mol Immunol 44, 3751-3757.

Shiratsuchi A., Umeda M., Ohba Y. and Nakanishi Y. (1997) Recognition of phosphatidylserine on the surface of apoptotic spermatogenic cells and subsequent phagocytosis by Sertoli cells of the rat. J Biol Chem 272, 2354-2358.

Sitja-Bobadilla A. and Álvarez-Pellitero P. (1993) Population dynamics of Sphaerospora dicentrarchi Sitja-Bobadilla et Álvarez-Pellitero, 1992 and S. testicularis Sitja-Bobadilla et Álvarez-Pellitero, 1990 (Myxosporea: Bivalvulida) infections in wild and cultured Mediterranean sea bass (Dicentrarchus labrax L.). Parasitology 106 ( Pt 1), 39-45.

Skaar K. S., Nobrega R. H., Magaraki A., Olsen L. C., Schulz R. W. and Male R. (2011) Proteolytically activated, recombinant anti-mullerian hormone inhibits androgen secretion, proliferation, and differentiation of spermatogonia in adult zebrafish testis organ cultures. Endocrinology 152, 3527-3540.

Socorro S., Martins R. S., Deloffre L., Mylonas C. C. and Canario A. V. (2007) A cDNA for European sea bass (Dicentrachus labrax) 11 beta-hydroxylase: gene expression during the thermosensitive period and gonadogenesis. Gen Comp Endocrinol 150, 164-173.

Terova G., Cattaneo A. G., Preziosa E., Bernardini G. and Saroglia M. (2011) Impact of acute stress on antimicrobial polypeptides mRNA copy number in several tissues of marine sea bass (Dicentrarchus labrax). BMC Immunol 12, 69.

Valero Y., Chaves-Pozo E., Meseguer J., Esteban M.A., Cuesta A. (2013) Biological role of fish antimicrobial peptides. In Antimicrobial Peptides: Properties, Functions and Role in Immune Response (Edited by Seong M.D. and Hak Y.I.),: p. 31-60. Nova Science Publishers, Inc.

Yan W., Ma L., Burns K. H. and Matzuk M. M. (2003) HILS1 is a spermatid-specific linker histone H1-like protein implicated in chromatin remodeling during mammalian spermiogenesis. Proc Natl Acad Sci U S A 100, 10546-10551.

\section{Figure legends}


663 Figure 1. GSI (a) and testicular sections stained with hematoxylin-eosin (HE; b-j) of 664 one year old European sea bass males. Resting (R) stage (b,c). Early (d), midd (e) and 665 late (f) spermatogenesis (SPG) stage. Spawning (S) stage (g,h). Post-spawning (PS) 666 stage $(i, j)$. Letters denoted statistically significant differences between groups $(\mathrm{P} \leq 0.05)$ 667 (n=8 fish/month). SG: spermatogonia; SC: spermatocytes; SD: spermatids; SZ: 668 spermatozoa; Arrow: interstitial cells; black arrowheads: Sertoli cells enclosing a 669 spermatogonium; white arrowheads: Sertoli cells limited the lumen of the tubules; 670 asterisks: spermatogonia. Scale bars $=25 \mu \mathrm{m}(\mathrm{c}, \mathrm{j})$ and $50 \mu \mathrm{m}(\mathrm{b}, \mathrm{d}-\mathrm{i})$.

671 Figure 2. The mean of the immunostaining rates (immunostaining area/total optical 672 area) with anti-BrdU (a) and testicular sections of one year old European sea bass males 673 immunostained with anti-BrdU at resting (R) (b), spermatogenesis (SPG) (c), spawning 674 (S) (d) and post-spawning (SP) (e) stages showing proliferative spermatogonia (black 675 arrows), and Sertoli cells (white arrowheads).L: lumen of the tubules. Letters denoted statistically significant differences between groups $(\mathrm{P} \leq 0.05) \quad(\mathrm{n}=10$ fish/reproductive stage). Scale bars $=30 \mu \mathrm{m}(\mathrm{b}-\mathrm{e})$.

678 Figure 3. The mean of the immunostaining rates (immunostaining area/total optical 679 area) with TUNEL (a) and testicular sections of one year old European sea bass stained 680 with TUNEL at resting (R) (b), spermatogenesis (SPG) (c), spawning (S) (d-f) and post681 spawning (PS) (g) stages showing apoptotic spermatogonia (white arrowheads), Sertoli 682 cells (black arrows) and spermatozoa (white arrows). Notice (f) that some Sertoli cells 683 that limited the lumen of the tubules have apoptotic spermatozoa phagocyted in their 684 cytoplasm (black arrowheads). Asterisks denoted the nuclei of the Sertoli cells. ED: 685 efferent duct. Letters denoted statistically significant differences between groups 686 $(\mathrm{P} \leq 0.05)(\mathrm{n}=10 \mathrm{fish} /$ reproductive stage $)$. Scale bars $=15 \mu \mathrm{m}(\mathrm{d}, \mathrm{e}, \mathrm{f}, \mathrm{g}), 25 \mu \mathrm{m}(\mathrm{c})$ and 50 $687 \mu \mathrm{m}(\mathrm{b})$. 
688 Figure 4. Sex steroid levels of testosterone (T) (a), 11-ketotestosterone (11KT) (b), 689 dihydrotestosterone (DHT) (c) and 17ß-estradiol $\left(\mathrm{E}_{2}\right)$ in the serum of one year old 690 European sea bass males through the reproductive cycle. R: resting stage; SPG: 691 spermatogenesis stage; S: spawning stage; PS: post-spawning stage. Letters denoted 692 statistically significant differences between groups $(\mathrm{P} \leq 0.05)(\mathrm{n}=4-6$ fish/reproductive 693 stage).

694 Figure 5. Expression of reproductive cyp11b1 (a), dhs3b (b), cyp19a1a (c), amh (d), $695 f$ shr (e), erb1 (f) and erb2 (g) genes in the testis of one year old European sea bass 696 males through a reproductive cycle. R: resting stage; SPG: spermatogenesis stage; S: 697 spawning stage; PS: post-spawning stage. Letters denoted statistically significant 698 differences between groups $(\mathrm{P} \leq 0.05)(\mathrm{n}=7-12$ fish/reproductive stage $)$.

699 Figure 6. Expression of the cytokines il1b (a), il6 (b) and tnfa (c) as well as lymphocyte 700 markers ighm (d) and tcrb (e) genes in the testis of one year old European sea bass males through a reproductive cycle. R: resting stage; SPG: spermatogenesis stage; $\mathrm{S}$ : spawning stage; PS: post-spawning stage. Letters denoted statistically significant differences between groups $(\mathrm{P} \leq 0.05)(\mathrm{n}=7-12$ fish/reproductive stage $)$.

Figure 7. Expression of viral recognition molecules mda5 (a) and lgp2 (b), anti-viral signalling pathway molecules tbk1 (c) and $\operatorname{irf3}(\mathrm{d})$ and anti-viral response molecules ifn (e), $p k r(\mathrm{f})$ and $m x(\mathrm{~g})$ coding genes in the testis of one year old European sea bass

707 males through a reproductive cycle. R: resting stage; SPG: spermatogenesis stage; S: 708 spawning stage; PS: post-spawning stage. Letters denoted statistically significant 709 differences between groups $(\mathrm{P} \leq 0.05)(\mathrm{n}=7-12$ fish/reproductive stage $)$.

710 Figure 8. Expression of anti-microbial peptide lyz (a), c3 (b), dic (c), hamp (d) h1 (e) 711 and $h 2 b$ (f) genes in the testis of one year old European sea bass males through a 
712 reproductive cycle. R: resting stage; SPG: spermatogenesis stage; S: spawning stage;

713 PS: post-spawning stage. Letters denoted statistically significant differences between

714 groups $(\mathrm{P} \leq 0.05)(\mathrm{n}=7-12$ fish/reproductive stage $)$.

715

716

717

718

719

720 
Highlights

1. In one year old European sea bass males, the testis undergoes the complete spermatogenesis process and steroidogenesis.

2. We have described for the first time that European sea bass males have detecting levels of $\mathrm{E}_{2}$ and DHT in serum.

3. The levels of expression of several relevant-immune genes suggest an important role for antimicrobial peptides in the defence of the reproductive tissues. 


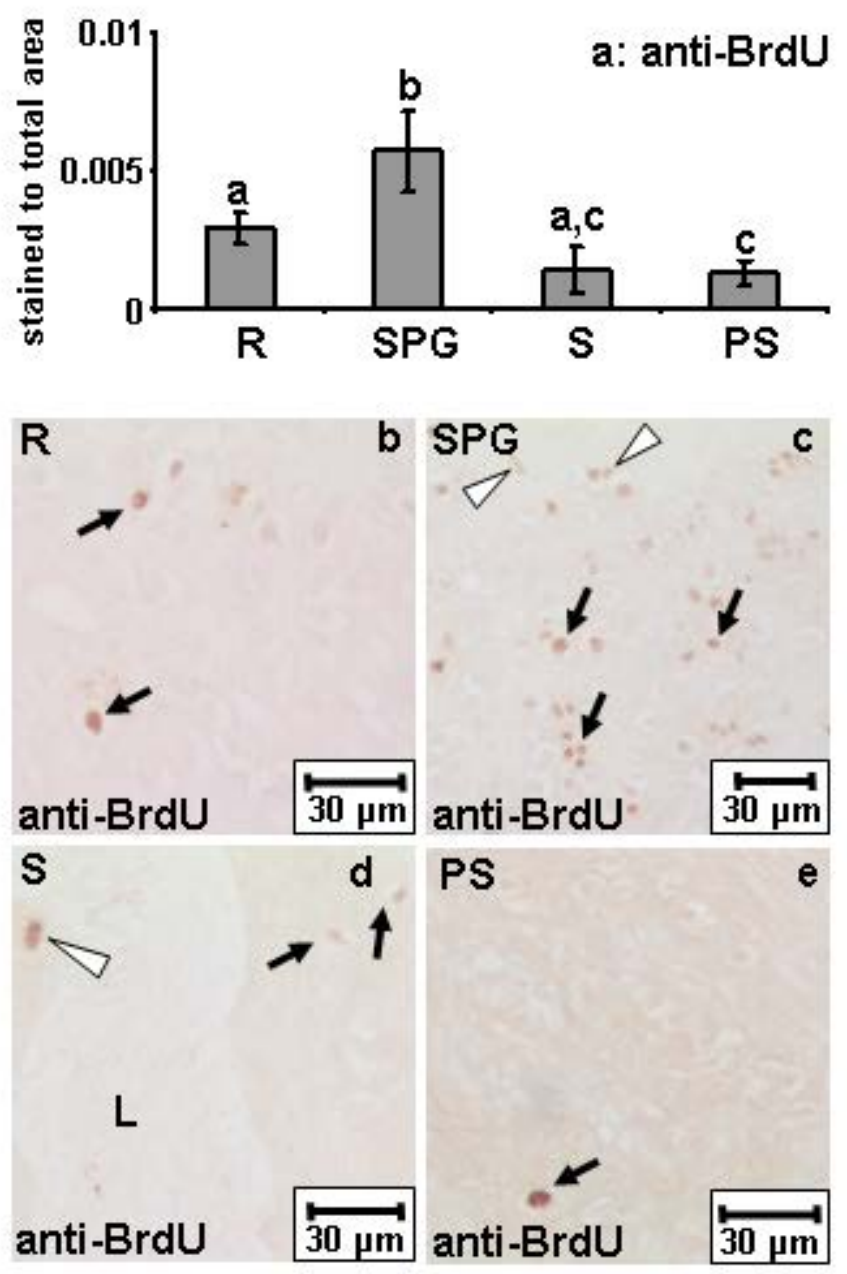




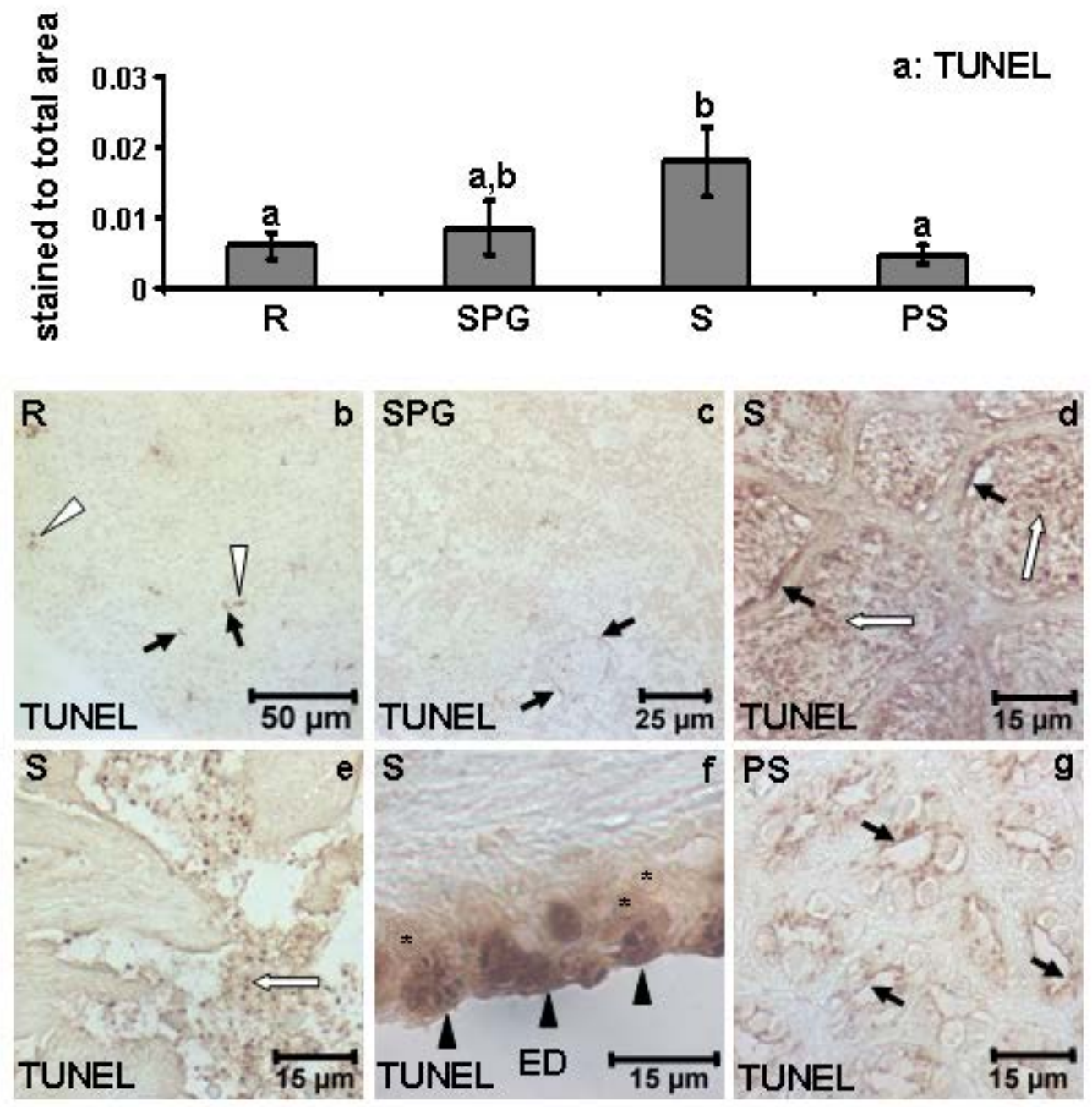



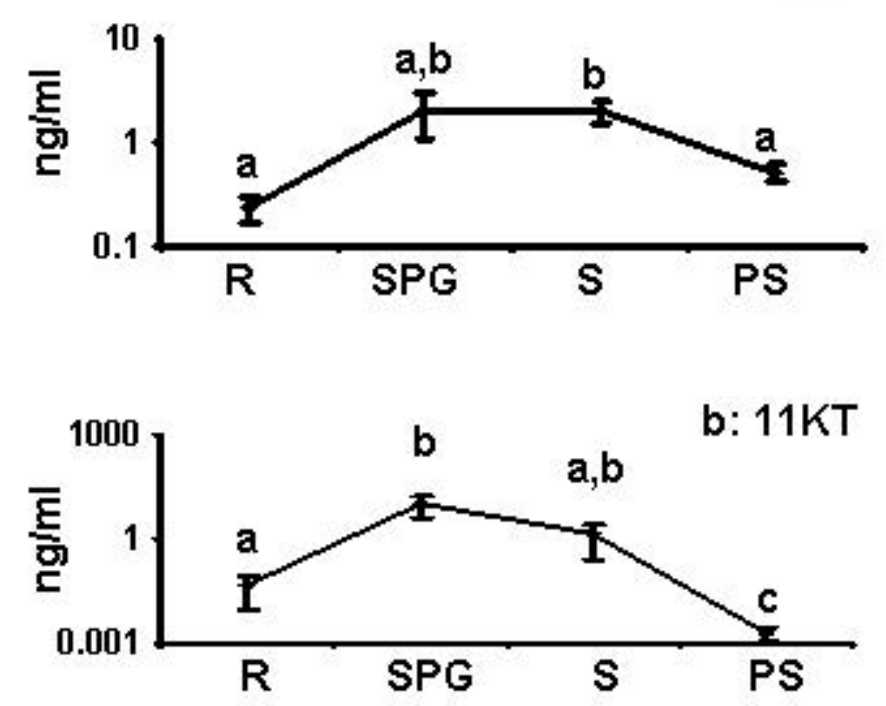

c: DHT
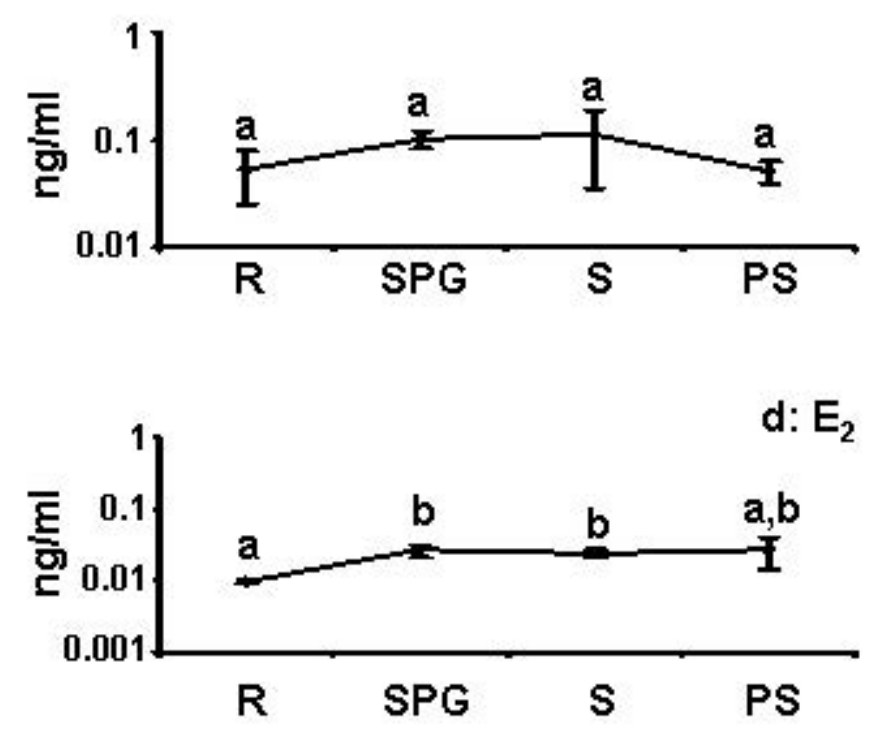


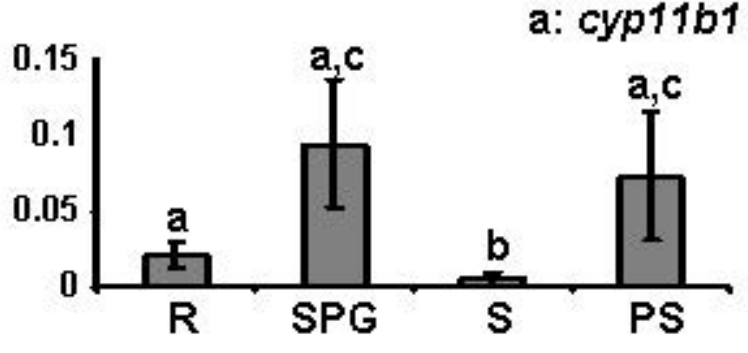

b: $d h s 3 b$

$\frac{5}{0}$
$\frac{0}{0}$
0
$\frac{0}{2}$
$\frac{0}{x}$
0
$\frac{0}{5}$
$\frac{5}{0}$
$\frac{5}{0}$
0
0

0.02

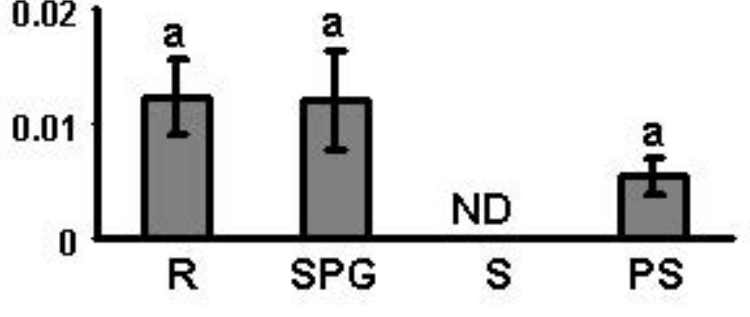

c: cyp19a1a

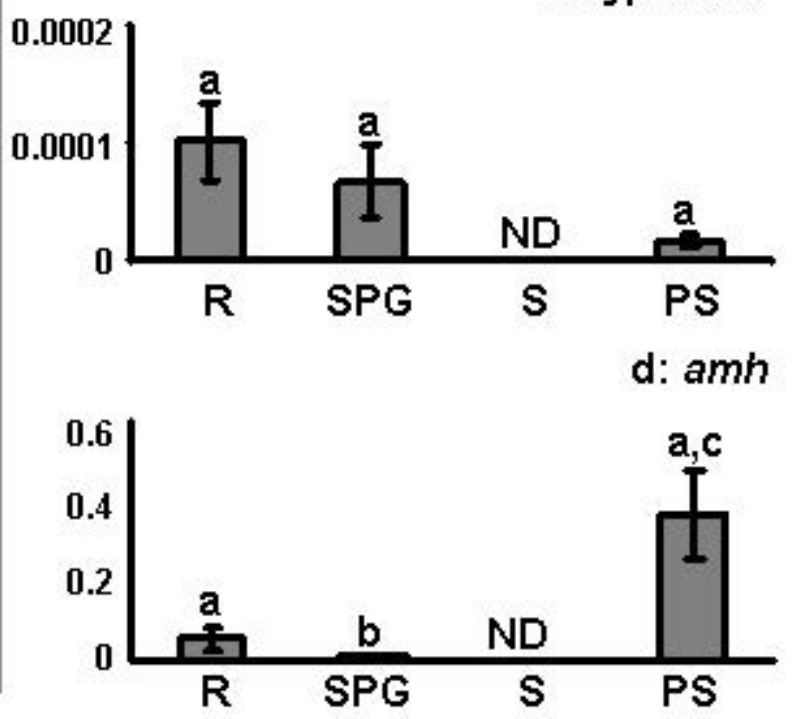

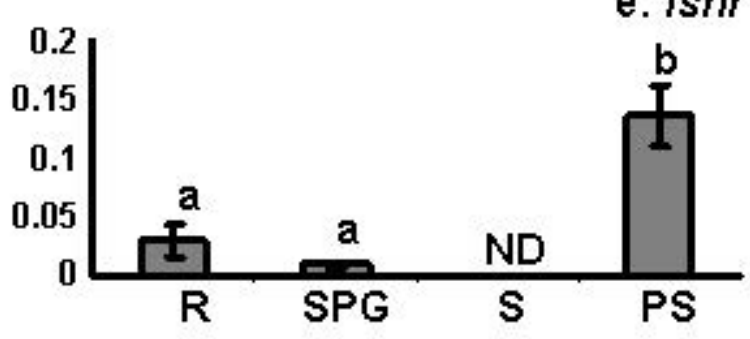

f: erb1

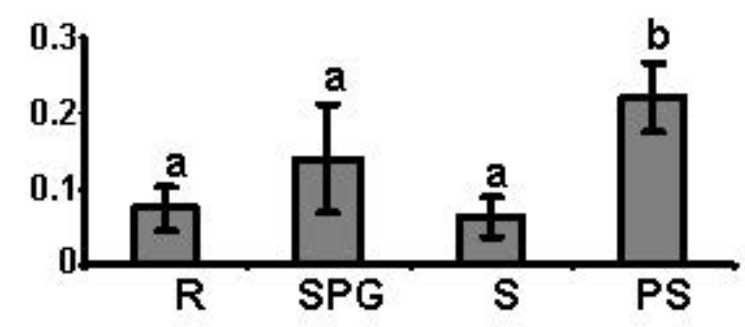

g: erb2

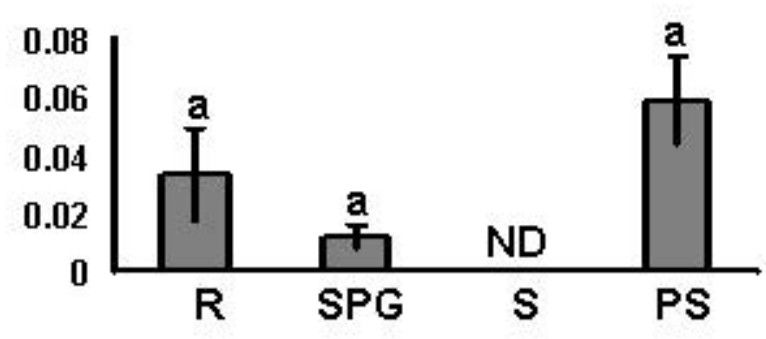




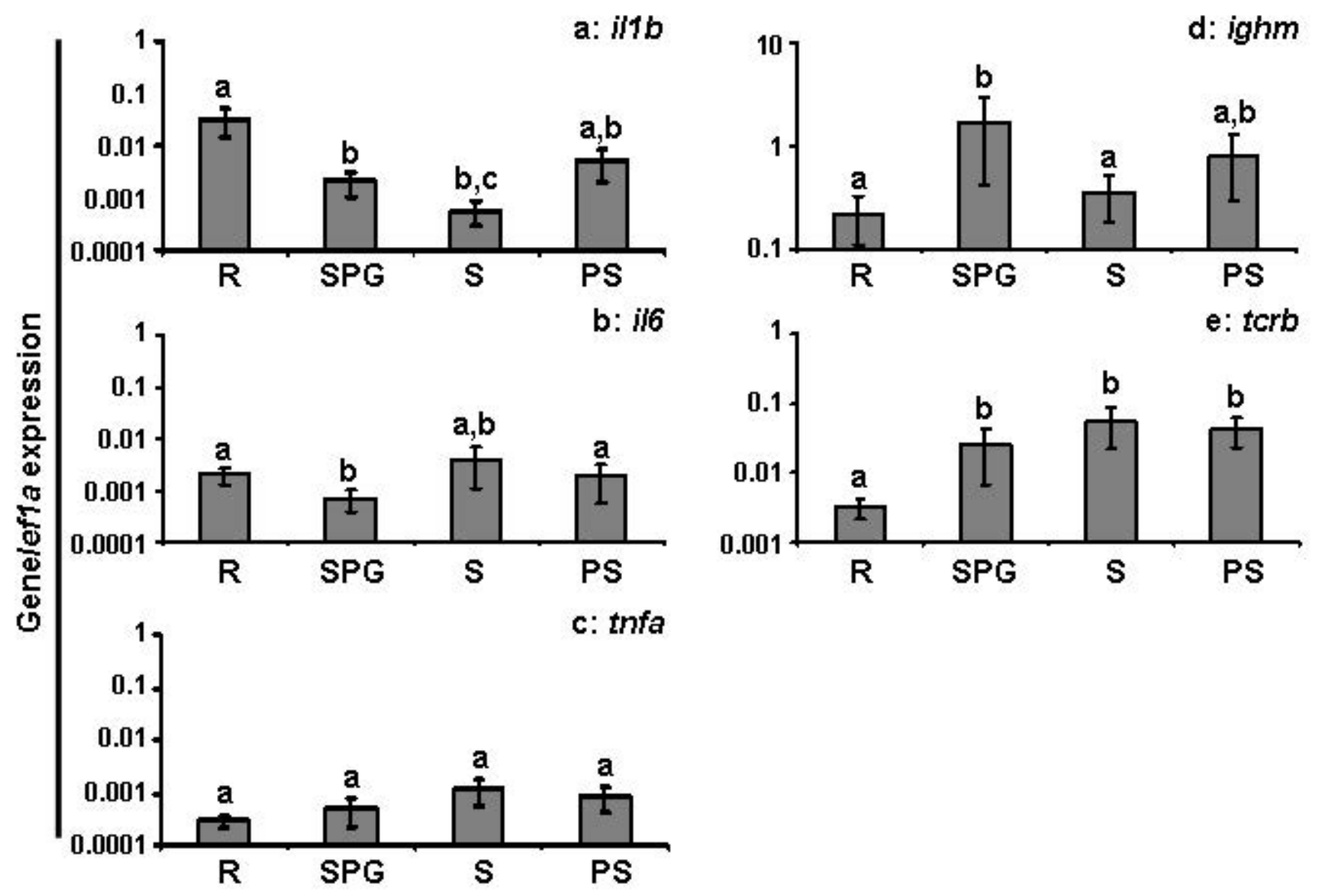




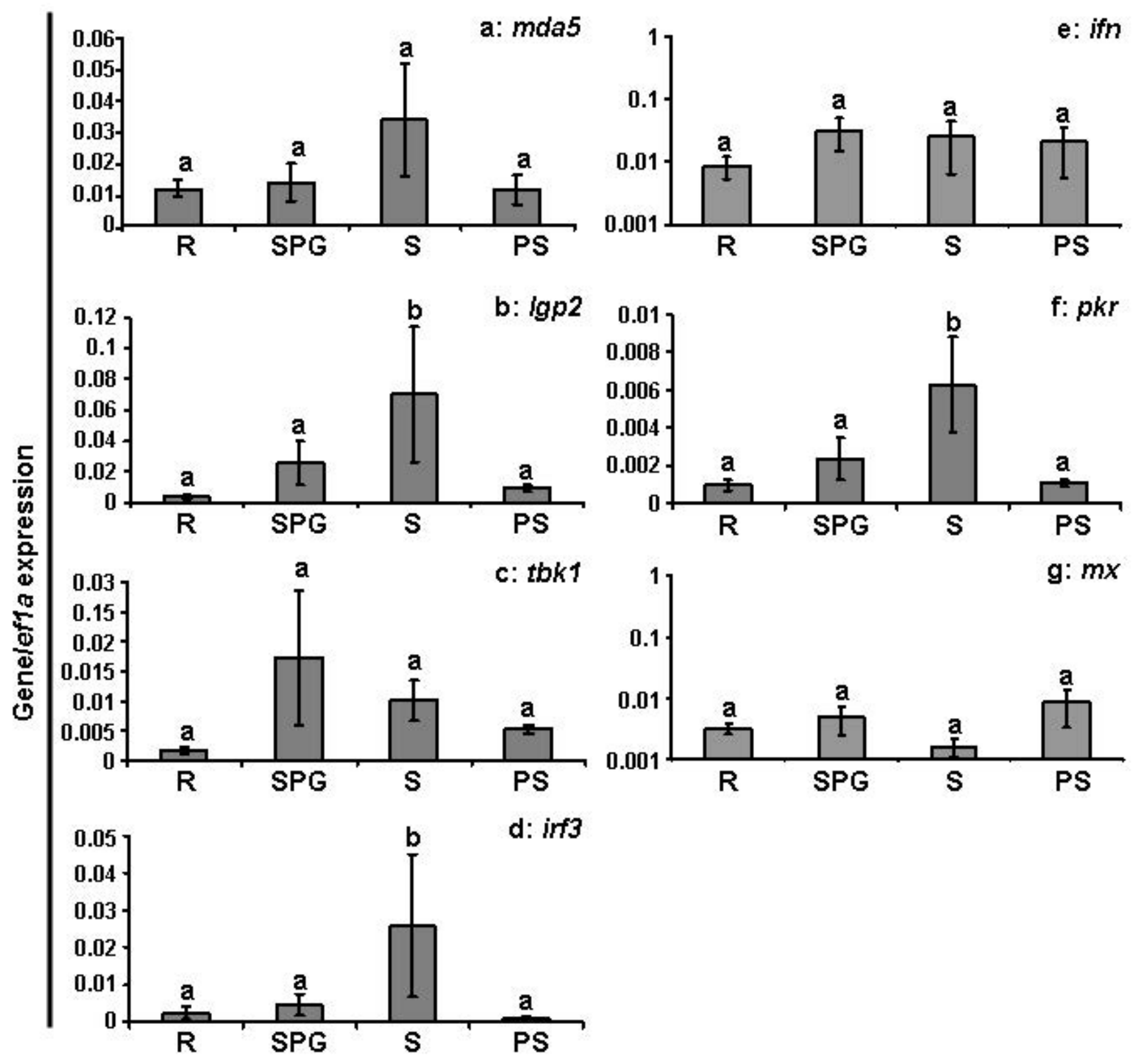




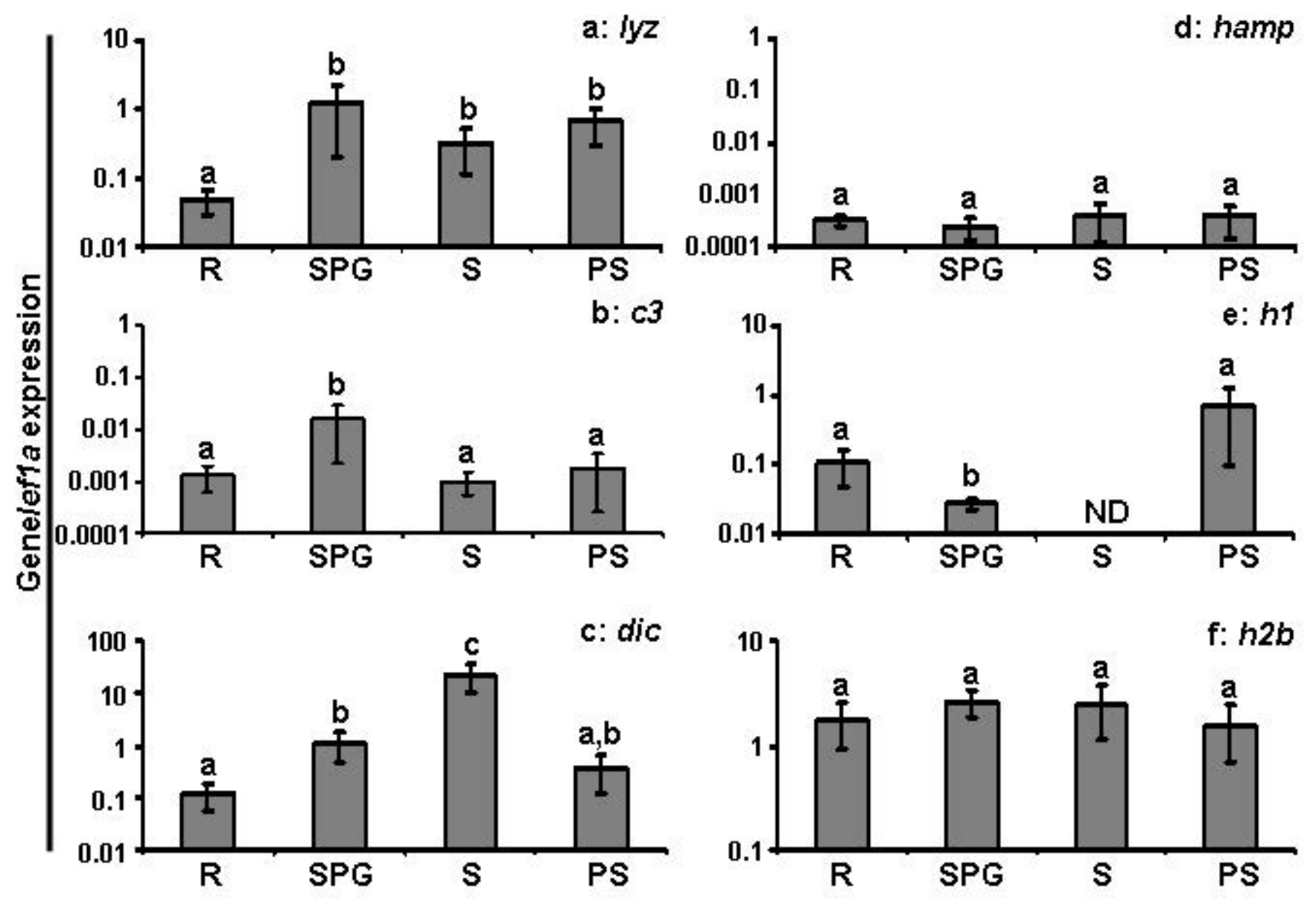


Table 1: Genes and primer sequences used for gene expression analysis. ESTs, expression sequences tags. GenBank (http://www.ncbi.nlm.nih.gov/genbank).

\begin{tabular}{|c|c|c|c|c|}
\hline Protein name & $\begin{array}{c}\text { Gene } \\
\text { abbreviation }\end{array}$ & Acc.number & Sequence (5’-3’) & Source of the sequences \\
\hline \multirow{2}{*}{$\begin{array}{l}\text { Steroid 11- } \beta \text { - } \\
\text { hydroxylase }\end{array}$} & \multirow{2}{*}{ cyp11b1 } & \multirow{2}{*}{ AF449173 } & CCCATCTACAGGGAGCATGT & \multirow{2}{*}{ (Socorro et al., 2007) } \\
\hline & & & GGAAGACTCCTTTGCTGTGC & \\
\hline \multirow{2}{*}{$\begin{array}{c}\text { 3 } \beta \text {-hydroxysteroid } \\
\text { dehydrogenase }\end{array}$} & \multirow{2}{*}{$d h s 3 b$} & \multirow{2}{*}{ FF578926 } & CACCTCTGGGCTTCAACATT & \multirow{2}{*}{ ESTs } \\
\hline & & & GTGCTTCCTCCCACGTGTAT & \\
\hline \multirow{2}{*}{ Aromatase } & \multirow{2}{*}{ сур19a1a } & \multirow{2}{*}{$\begin{array}{l}\text { AJ298290, } \\
\text { AJ311177 }\end{array}$} & CTGGAGCCACACAGACAAGA & \multirow{2}{*}{ (Blazquez et al., 2008) } \\
\hline & & & AACTGAGGCCCTGCTGAGTA & \\
\hline \multirow{2}{*}{$\begin{array}{l}\text { Anti-Mullerian } \\
\text { hormone }\end{array}$} & \multirow{2}{*}{$a m h$} & \multirow{2}{*}{ AM232703 } & TGCAGGTCTCACAAGGACTG & \multirow{2}{*}{ (Halm et al., 2007) } \\
\hline & & & CTGGATGCAAAACCTCCAAT & \\
\hline \multirow{2}{*}{$\begin{array}{l}\text { Follicle stimulating } \\
\text { hormone receptor }\end{array}$} & \multirow{2}{*}{ fshr } & \multirow{2}{*}{ AY642113 } & АСТССАССТССАТСАТСТGC & \multirow{2}{*}{ (Rocha et al., 2007) } \\
\hline & & & AACGGGGAACAGTCAGTTTG & \\
\hline \multirow{2}{*}{ Estrogen receptor $\beta 1$} & \multirow{2}{*}{ erb1 } & \multirow{2}{*}{ AJ489523 } & GGGTGAGAGAGCTCAAGCTC & \multirow{2}{*}{ (Halm et al., 2004) } \\
\hline & & & AAGCTAAGGCCGGTTTTGGC & \\
\hline \multirow{2}{*}{ Estrogen receptor $\beta 2$} & \multirow{2}{*}{ erb2 } & \multirow{2}{*}{ AJ489524 } & AGTGGGCATGATGAAGTGCG & \multirow{2}{*}{ (Halm et al., 2004) } \\
\hline & & & TGCACGTGGTTCACCTGAGG & \\
\hline \multirow{2}{*}{ Interleukin $1 \beta$} & \multirow{2}{*}{$i l 1 b$} & \multirow{2}{*}{ AJ269472 } & CAGGACTCCGGTTTGAACAT & (Scapigliati et al. 2001) \\
\hline & & & GTCCATTCAAAAGGGGACAA & (Scap1gliati et al., 2001) \\
\hline & & & ACTTCCAAAACATGCCCTGA & (Senulcre et al 2007) \\
\hline Interleukin 6 & 116 & AM490062 & CCGCTGGTCAGTCTAAGGAG & (sepulcre et al., 2007) \\
\hline Tumor necrosis factor- & $\operatorname{tnf} a$ & DO200010 & AGCCACAGGATCTGGAGCTA & Nascimento et al 2007 ) \\
\hline$\alpha$ & inja & DQ200910 & GTCCGCTTCTGTAGCTGTCC & (Nascimento et al., 200/) \\
\hline Heavy chain of & iahm & FN908858 & AGGACAGGACTGCTGCTGTT & GenBank \\
\hline immunoglobulin $\mathrm{M}$ & Igmiा & ГN900050 & CACCTGCTGTCTGCTGTTGT & UEMDÄK \\
\hline$\beta$ subunit of T-cell & & & GACGGACGAAGCTGCCCA & \\
\hline receptor & tcrb & FN68/461 & TGGCAGCCTGTGTGATCTTCA & (Buonocore et al., 2012) \\
\hline $\begin{array}{c}\text { Melanoma } \\
\text { differentiation- }\end{array}$ & mda5 & AM986362 & AATTCGGCAATGGTGAAGTC & ESTs \\
\hline & & & TCATTGGTCACAAGGCCATA & \\
\hline Laboratory of genetics & & & TGATGGCAGTCAGTGGAGAG & \\
\hline $\begin{array}{c}\text { and physiology } 2 \\
\text { protein }\end{array}$ & $\operatorname{lgp} 2$ & AM984225 & TGAGAGCTCAACGTGTTTGG & ESTs \\
\hline TANK-binding kinase & thk1 & FM013306 & ACAAGGTCCTGGTGATGGAG & $\mathrm{EST}_{\mathrm{T}}$ \\
\hline 1 & LOKI & FIVI015000 & CGTCCTCAGGAAGTCCGTAA & ESIS \\
\hline Interferon regulatory & irf3 & CBN81356 & AGAGGTGAGTGGCAATGGTC & GenBank \\
\hline
\end{tabular}




\begin{tabular}{|c|c|c|c|c|}
\hline factor 3 & & & GAGCAGTTTGAAGCCTTTGG & \\
\hline \multirow{2}{*}{ Interferon } & \multirow{2}{*}{ ifn } & \multirow{2}{*}{ AM765847 } & GGCTCTACTGGATACGATGGC & \multirow{2}{*}{ (Casani et al., 2009) } \\
\hline & & & CTCCCATGATGCAGAGCTGTG & \\
\hline \multirow{2}{*}{$\begin{array}{l}\text { dsRNA-dependent } \\
\text { protein kinase }\end{array}$} & \multirow{2}{*}{$p k r$} & \multirow{2}{*}{ FM008342 } & AGGGTCAGAGCATCAAGGAA & \multirow{2}{*}{ ESTs } \\
\hline & & & GACACCTTGCTGTCCCAGTC & \\
\hline \multirow{2}{*}{$\begin{array}{l}\text { Myxovirus (influenza) } \\
\text { resistance proteins }\end{array}$} & \multirow{2}{*}{$m x$} & \multirow{2}{*}{$\begin{array}{l}\text { AM228977, } \\
\text { HQ237501, } \\
\text { AY424961 }\end{array}$} & GAAGAAGGGCTACATGATCGTC & \multirow{2}{*}{ (Scapigliati et al., 2010) } \\
\hline & & & CCGTCATTGTAGAGAGTGTGGA & \\
\hline \multirow{2}{*}{ Lysozyme } & \multirow{2}{*}{ lyz } & \multirow{2}{*}{ FN667957 } & ATTTCCTGGCTGGAACACAG & \multirow{2}{*}{ (Buonocore et al., 2014) } \\
\hline & & & GAGCTCTGGCAACAACATCA & \\
\hline \multirow{2}{*}{$\begin{array}{l}\text { Complement } \\
\text { component } 3\end{array}$} & \multirow{2}{*}{$c 3$} & \multirow{2}{*}{ HM563078 } & ACCAAAGAACTGGCAACCAC & \multirow{2}{*}{ (Mauri et al., 2011) } \\
\hline & & & CTAGCAGTCGGTCAGGGAAC & \\
\hline \multirow{2}{*}{ Dicentracin } & \multirow{2}{*}{ dic } & \multirow{2}{*}{ AY303949 } & GGCAAGTCCATCCACAAACT & \multirow{2}{*}{ (Salerno et al., 2007) } \\
\hline & & & ATATTGCTCCGCTTGCTGAT & \\
\hline \multirow{2}{*}{ Hepcidin } & \multirow{2}{*}{ hamp } & \multirow{2}{*}{ DQ131605 } & CCAGTCACTGAGGTGCAAGA & \multirow{2}{*}{ (Rodrigues et al., 2006) } \\
\hline & & & GCTGTGACGCTTGTGTCTGT & \\
\hline \multirow{2}{*}{ Histone H1 } & \multirow{2}{*}{$h 1$} & \multirow{2}{*}{ JN410661 } & AAGAAGACGGGTCCCTCAGT & \multirow{2}{*}{ (Terova et al., 2011) } \\
\hline & & & CTTGACCTTCTTCGCTTTGG & \\
\hline \multirow{2}{*}{ Histone $\mathrm{H} 2 \mathrm{~B}$} & \multirow{2}{*}{$h 2 b$} & \multirow{2}{*}{ JN410660 } & GGAGAGCTACGCCATCTACG & \multirow{2}{*}{ (Terova et al., 2011) } \\
\hline & & & GCTCAAAGATGTCGCTCACA & \\
\hline Flongution foctor 10 & flo & $A$ IQ66727 & CGTTGGCTTCAACATCAAGA & ConDontr $\mathrm{x}$ \\
\hline Eiongation ractor id & e/1a & Аग $000 / 21$ & GAAGTTGTCTGCTCCCTTGG & Uenbank \\
\hline
\end{tabular}


Table 2. Identification of the interest genes in the expressed sequence tags (ESTs) databases and their relation with the zebrafish orthologs.

\begin{tabular}{|c|c|c|c|c|c|}
\hline $\begin{array}{c}\text { Predicted } \\
\text { protein }\end{array}$ & Fish specie & $\begin{array}{c}\text { Gene acc. } \\
\text { number }\end{array}$ & $\begin{array}{c}\text { Protein } \\
\text { length }\end{array}$ & $\begin{array}{c}\text { Protein } \\
\text { homology }\end{array}$ & E-value $^{\mathrm{b}}$ \\
\hline \multirow{2}{*}{ dhs3b } & $\begin{array}{c}\text { Sea bass } \\
\text { Zebrafish }\end{array}$ & $\begin{array}{c}\text { FF578926 } \\
\text { NP_997962 }\end{array}$ & $\begin{array}{c}185 \\
374\end{array}$ & 72 & $7 \mathrm{e}-70$ \\
\hline \multirow{2}{*}{ lgp2 } & Sea bass & AM986362 & 206 & 72 & $1 \mathrm{e}-91$ \\
& Zebrafish & XP_694124 & 997 & & $2 \mathrm{e}-115$ \\
\hline \multirow{2}{*}{$t b k 1$} & Zea bass & AM984225 & 297 & 71 & 3e-33 \\
& Sea bass & FM013306 & 220 & 95 & $1 \mathrm{e}-41$ \\
\hline \multirow{2}{*}{$p k r$} & Sebrafish & NP_001038213 & 727 & & \\
\hline
\end{tabular}

Percentage of homology $\left({ }^{a}\right)$ and E-value $\left({ }^{b}\right)$ of the predicted proteins respect to the zebrafish ortholog. 
Table 3: Correlations observed between the sex hormone levels in serum and reproductive related gene expressions in gonad of one year old European sea bass males throughout a reproductive cycle. The first number corresponds to Pearson coefficient of correlation and the second to the significant difference P. Written in bolds are the parameters that correlated.

\begin{tabular}{|c|c|c|c|c|c|c|c|c|c|c|}
\hline & $11 \mathrm{KT}$ & DHT & $E_{2}$ & cyp11b1 & $d h s 3 b$ & сур19a1a & $a m h$ & erb1 & erb2 & fshr \\
\hline \multirow{2}{*}{$\mathrm{T}$} & 0.715 & 0.557 & 0.345 & -0.295 & 0.608 & $\begin{array}{l}-0.525 \\
\end{array}$ & -0.250 & -0.143 & 0.296 & -0.265 \\
\hline & 0.002 & 0.025 & 0.190 & 0.267 & 0.027 & 0.065 & 0.369 & 0.625 & 0.350 & 0.382 \\
\hline \multirow{2}{*}{$11 \mathrm{KT}$} & & 0.299 & 0.238 & -0.221 & 0.228 & -0.311 & -0.153 & -0.173 & 0.127 & -0.202 \\
\hline & & 0.261 & 0.375 & 0.411 & 0.453 & 0.300 & 0.587 & 0.554 & 0.694 & 0.508 \\
\hline \multirow{2}{*}{ DHT } & & & 0.328 & -0.057 & 0.141 & -0.271 & -0.087 & -0.039 & -0.219 & -0.239 \\
\hline & & & 0.215 & 0.834 & 0.646 & 0.370 & 0.758 & 0.895 & 0.494 & 0.431 \\
\hline \multirow{2}{*}{$\mathrm{E}_{2}$} & & & & 0.693 & 0.285 & 0.253 & -0.236 & 0.257 & 0.093 & -0.241 \\
\hline & & & & 0.003 & 0.345 & 0.405 & 0.397 & 0.374 & 0.773 & 0.427 \\
\hline \multirow{2}{*}{ cyp11b1 } & & & & & -0.311 & 0.445 & 0.525 & 0.393 & 0.161 & 0.557 \\
\hline & & & & & 0.149 & 0.043 & 0.008 & 0.035 & 0.485 & 0.007 \\
\hline \multirow{2}{*}{$d h s 3 b$} & & & & & & 0.028 & -0.319 & -0.252 & -0.133 & -0.470 \\
\hline & & & & & & 0.908 & 0.159 & 0.257 & 0.576 & 0.031 \\
\hline \multirow{2}{*}{ сур19a1a } & & & & & & & -0.308 & -0.082 & 0.070 & -0.120 \\
\hline & & & & & & & 0.199 & 0.723 & 0.788 & 0.625 \\
\hline \multirow{2}{*}{ amh } & & & & & & & & 0.307 & 0.661 & 0.885 \\
\hline & & & & & & & & 0.165 & 0.002 & 0.000 \\
\hline \multirow{2}{*}{ erb1 } & & & & & & & & & 0.600 & 0.628 \\
\hline & & & & & & & & & 0.005 & 0.002 \\
\hline erb2 & & & & & & & & & & 0.708 \\
\hline
\end{tabular}

